\title{
Lessons from Jojo
}

\section{Organizing Side-by-Side with Power, Heart, and Grace}

\author{
Dina Shek
}

I write this while taking a "break" from the flood of non-medical pandemic emergencies that all social and legal service providers - and so many community members-face today. But there is no break. I tried to schedule writing days, but had to make exception after exception to jump on a Zoom call to discuss unlawful evictions violating the Governor's emergency moratorium, to help someone file their unemployment claims after being illegally denied access to an interpreter, and to find resources for a household needing food and basic supplies while self-quarantining after possible COVID-19 exposure.

And as I sit here dreaming of a better future, I have one wish for policymakers and government leaders who set the tone for how we move forward. Believe- and act as if - all people have the right and the capacity to lead themselves. Most often, this simple but primary factor is missing from policy decisions, organizing actions, and service provider work. Approaches that treat communities as charity cases to be saved, or clients to be served, dominate the landscape, but do little to transform systems or create meaningful change. Government leaders and policymakers must engage those they consider "vulnerable," and service providers must engage their "clients" as people worthy of power and autonomy. We must value their experiences, solutions, and goals, and more often than not, defer to their leadership.

\section{Organizing Policy is Health Policy}

For eleven years, our Medical-Legal Partnership for Children in Hawai'i program has centered community organizing - rooted in the belief that people have the right to lead themselves — as a core social determinant of health. Medical-Legal Partnership programs have long proclaimed that "housing policy is health policy," "education policy is health policy," and "employment policy is health policy." Now, in the midst of a pandemic and looming and cascading economic and health crises, these tenets seem self-evident. For instance, an eviction moratorium keeping people safely housed during a pandemic is obviously a health policy. We must now embrace that "organizing policy is health policy." 
Public health scholar Camara Phyllis Jones, MD, MPH, PhD, offers a "global definition of racism" that is a helpful tool for framing our "organizing health policy" and "community lawyering" approaches:

Racism is a system of structuring opportunity and assigning value based on phenotype ("race"), that:

- unfairly disadvantages some individuals and communities

- unfairly advantages other individuals and communities

- undermines realization of the full potential of the whole society through the waste of human resources. (10)

This translates into our foundational value that every person has the right to realize their full potential. A system that wastes "human resources" and undermines people's power and autonomy is a racist system that harms us all.

\section{Uncovering Shared Values in Community Organizing}

What follows are some values I have learned from working and organizing alongside Micronesian communities in Hawai $i$, and especially from my organizing partnership and friendship with the late Joakim "Jojo" Peter, $\mathrm{PhD}$. Jojo was a brilliant, compassionate, and fierce advocate, scholar, educator, friend, and champion of his people-Oceania, Micronesia, Chuuk, Ettal. I still hear Jojo in my head and my heart during these most difficult times, urging our far-reaching organizing family to act with the urgency and deep well of love that he did every single day.

\section{Believe that all people have the right and the capacity to lead themselves.}

The resurgent fight for Black lives has shined the light on how difficult it is for some to see "others" as deserving of voice, of knowledge, and of life. We must confront this in all aspects of our lives and work. Jojo knew better than most how his very presence-a brown-skinned Micronesian and quadriplegic wheelchair-userinvoked a sense of "other." He masterfully drew people in with his quick smile, easy banter, and invitations to help. The simple request of adding cream and Splenda to his coffee might later lead to an invitation to join a Micronesian-led meeting to support a policy effort. Jojo had little tolerance for meetings that treated Micronesians as "those vulnerable people," but he would participate and shift the tenor so people saw that we are all connected, and we must act as one community. In Jojo's thoughtful presence, people found ways to act with, not only for, others.

As a supervisor and teacher, I have my staff and students read and discuss Gerald López's Rebellious Lawyering and Camara Jones's analyses of racism. We work side-by-side with people often designated as "clients" and "those we help" so they become our partners and educators instead. We learn to shut up and listen. We listen to stories, solutions, and visions for the future. We connect with those parts 
that resonate with our own hopes and dreams, and we hold our differences with respect and dignity. And through this, we share tools to uplift, and we become each others' resources. We learn that lawyering and problem-solving and educating flow both ways. The beautifully unyielding Black Lives Matter movement has forced a reckoning in all of us to realize a climate where these self-reflective approaches just might begin to truly take hold.

\section{Seek to develop meaning ful relationships and build trust.}

This may seem obvious. But how do you build relationships? How do you move from provider-client to trusted community partners? Strong relationships take time. Strong relationships take commitment. Sometimes building relationships demands stepping outside of your bubble, entering into difficult conversations and unfamiliar spaces. It can be as simple as grabbing coffee with a new face at the table - preferably with someone who doesn't look like you or share your role-to learn about their goals and prior experiences, and to share ideas. And when you hear about a community festival, sports event, rally, or these days, a Zoom town hall gathering, show up! Showing up to other people's events matters.

\section{$B$ ready to give grace and be grateful to receive grace.}

Organizing work is hard. Anyone who has "worked" a legislative session or any campaign knows that you sacrifice a lot. You give up time, stress your relationships, disagree with your opponents and your allies. But there are always moments of grace. You must be ready to give it when someone steps too far, and you need to step back. And you should recognize when grace is being granted to you. You'll know your community relationships are strong when you can do this.

Barely two weeks into 2019, during some contentious arguments over competing advocacy interests and priorities, Jojo sent me a chat message acknowledging that he was not "easy or fun to get along or work with sometimes," and that he got "too wound up." He apologized, and then wrote, "Just know that I always love you as my sister, not just as a mere friend or colleague." Grace.

\section{Everyone has a role to play (Jojo's "Fix your face!").}

Like any good organizer, Jojo was always very thoughtful about who should be at the table for various strategy sessions, meetings, and events. He also spent a lot of time identifying and encouraging rising leaders and scholars, often calling and video chatting with people across the country, convincing them to step up to leadership roles, return to school, or join a policy campaign. And when I would complain that someone was bringing too much ego or too little heart to our efforts, Jojo would remind me that they are part of the community. They want to help, so even if we were not completely aligned, they had a role to play. Innocenta, Jojo's lifelong 
friend and sister, joked that when she pursed her lips or rolled her eyes, Jojo would reprimand her by saying "Fix your face!" We cherish amusing and powerful remembrances of Jojo reminding us that we all need to work together. Everyone brings something to the table. Go ahead and vent to your friends, but then set it aside and get the work done.

\section{What would Jojo do?}

Though the loss of Jojo remains painful and present, his organizing family and legacy remain strong and committed. This pandemic has dramatically exposed longstanding divisions between state leadership and affected communities. Yet every single day, Micronesian communities lead public health education, policy campaigns, and grassroots actions. Now is a critical time for state leaders and policymakers to build meaningful relationships with the people and their work. State agencies could begin by taking two steps: (1) create community liaison positions in every agency to serve and connect communities without traditional access, and (2) pay people their worth-interpreters and translators, certainly, but also community members providing their knowledge and recommendations. That's what consulting funds are for, and who knows better how policies are working than those most affected by them?

Hawai' $\mathrm{i}$ will only recover and be stronger when we believe that everyone has the right and the capacity to lead themselves.

\section{Works Cited}

Jones, Camara Phyllis. “Confronting Institutionalized Racism.” Phylon, vol. 50, nos. 1/2, 2002, pp. 7-22.

. "Levels of Racism: A Theoretic Framework and a Gardener's Tale." American Journal of Public Health, vol. 90, no. 8, Aug. 2000, pp. 1212-15.

López, Gerald P. Rebellious Lawyering: One Chicano's Vision of Progressive Law Practice.

Westview Press, 1992.

Dina Shek is a licensed attorney and the Legal Director of the Medical-Legal Partnership for Children in Hawai ${ }^{i}$, which she co-founded in 2008 with Dr. Chris Derauf at Kokua Kalihi Valley Comprehensive Family Services. A Faculty Specialist and proud graduate of the William S. Richardson School of Law (UH Mānoa), she is the daughter and granddaughter of Japanese American wartime incarceration (Rohwer and Tule Lake camps) and owes a great debt to the activists and attorneys of the Japanese American Redress Movement. 